\title{
Determinants of Executive Compensation in Privately Held Firms
}

\author{
Banghøj, Jesper; Gabrielsen, Gorm; Vriborg Petersen, Christian; Plenborg, Thomas
}

Document Version

Final published version

Publication date:

2009

License

CC BY-NC-ND

Citation for published version (APA):

Banghøj, J., Gabrielsen, G. Vriborg Petersen, C., \& Plenborg, T. (2009). Determinants of Executive

Compensation in Privately Held Firms. Department of Accounting and Auditing, Copenhagen Business School.

Link to publication in CBS Research Portal

\section{General rights}

Copyright and moral rights for the publications made accessible in the public portal are retained by the authors and/or other copyright owners and it is a condition of accessing publications that users recognise and abide by the legal requirements associated with these rights.

\section{Take down policy}

If you believe that this document breaches copyright please contact us (research.lib@cbs.dk) providing details, and we will remove access to the work immediately and investigate your claim. 
Copenhagen

Business School

HANDELSHのJSKOLEN

\section{WP 2009-01}

Determinants of executive compensation in privately held firms

by

Assistant professor Jesper Banghøj

Associate professor Gorm Gabrielsen

Professor Christian Petersen

Professor Thomas Plenborg

Email:

jb.acc@cbs.dk

gg.fi@cbs.dk

cp.acc@cbs.dk

tp.acc@cbs.dk

INSTITUT FOR REGNSKAB OG REVISION, Handelshøjskolen i København

Solbjerg Plads 3, C.4., 2000 Frederiksberg

TIf.: 38152320 Fax: 38152321

DEPARTMENT OF ACCOUNTING AND AUDITING, Copenhagen Business School

Solbjerg Plads 3, C.4., DK-2000 Frederiksberg

Phone: +4538152320 Fax: +45 38152321

uk.cbs.dk/forskning_viden/institutter_centre/institutter/rr 


\section{Determinants of executive compensation in privately held firms}

\section{Abstract}

We examine what determines executive compensation in privately held firms. Our study is motivated by the fact that most studies in this area rely on data from publicly traded firms. Further, the few studies that are based on data from privately held firms only examine a limited number of determinants of executive compensation.

Our findings indicate that the pay to performance relation is weak. Board size and ownership concentration are the only corporate governance characteristics that explain variations in executive compensation. Executive characteristics like skills, title and educational attainment all explain variations in executive compensation. Contrary to our expectations we do not find a stronger pay to performance relation in firms with better designed bonus plans.

\section{Key words:}

Board characteristics, Compensation contracts, Executive characteristics, Performance measures, Quality of bonus plans.

${ }^{\mathrm{C}}$ Corresponding author

JEL classification code: M52 - Compensation and Compensation Methods and Their Effects

We acknowledge the helpful comments of workshop participants at Copenhagen Business School and the EAA congress 2008 in Rotterdam. 


\section{Determinants of executive compensation in privately held firms}

\section{Introduction}

The compensation of chief executive officers (CEOs) is a topic of great interest to both academics and practitioners. A considerable number of papers have examined what explains the level of executive compensation. With a few exceptions, these studies are based on data from publicly traded firms (Cole and Mehran, 2008). We add to the literature by examining what explains the level of executive compensation among privately held firms. We analyse a comprehensive set of determinants of executive compensation. Further, as a unique feature of our dataset, we are able to evaluate the quality of each executive's bonus plan. We are, therefore, able to explore if the expected positive pay to performance relation is stronger for better designed bonus plans. The majority of papers which examine the determinants of executive compensation rely on publicly available data from listed companies. For example, Ke et al. (1999) argue that published studies on compensation in privately held firms are 'essentially nonexistent because the data generally has not been accessible'. Cole and Mehran (2008) note that with a few exceptions, previous research on executive compensation focus on publicly traded companies that are required to file information on compensation with regulators. However, privately held firms have characteristics that deviate from listed firms and therefore may affect the design of compensation contracts. First, the corporate governance structure of privately held and publicly traded firms deviates. For example, the level of ownership concentration tends to be high in privately held firms as opposed to the often diffuse ownership structure of publicly traded firms (Ke et al., 1999). Thus, owners in privately held firms have better economic incentives to monitor the actions taken by executives (Fama and Jensen, 1983). They also have better access to executives. These elements therefore tend to reduce the need for performance related compensation, and owners of privately held firms should be more likely to employ a forcing contract with penalty of firing (Ke et al., 1999). On the other hand, there is a tendency that CEOs in privately held firms are more frequently member of the supervisory board than CEOs in publicly traded firms. For example, we find that $34.4 \%$ of the 
CEOs in privately held firms are member of the supervisory board. In comparison, only $17.6 \%$ of the CEOs in publicly traded firms in Denmark are member of the supervisory board. This will reduce the board's independence and may lead to inefficient compensation contracts. Second, Ball and Shivakumar (2005) find that earnings is a relatively more noisy measure of performance in privately held firms than in publicly traded firms. This implies that the pay to performance relation is relatively more distorted for privately held firms than for publicly traded firms. Third, since quoted share prices are not available for privately held firms it is likely that an executive compensation contract in a privately held firm emphasises fixed salary at the expense of performance related pay. In summary, privately held firms have characteristics that deviate from listed firms, which may affect both the design of compensation contract and the level of pay.

In Denmark more than $99 \%$ of all firms are privately held. A similar high level of privately held firms can be found in most other countries. Given that most firms are privately held it is surprising how little information on executive compensation that is available on these firms. Such studies could provide useful information that can be used to design better contracts and would obviously be of interest to executives, board members and shareholders. In a broader context, it is important to gain an understanding of executive compensation and how it affects performance in privately held firms given their dominating role in most economies. It is also essential to examine how factors such as board characteristics, ownership structures, and executive characteristics affect the design of compensation plans. Ultimately, firms with well designed compensation plans arguably generate more wealth to the society.

The few studies on privately held firms that examine determinants of executive compensation include a few explanatory variables only. As noted in Cole and Mehran (2008) data availability limit the number of testable hypotheses. Even studies that rely on publicly traded firms tend to focus on one or two groups of characteristics only. For example, Core et al. (1999) explore performance, board characteristics and ownership structures ignoring executive characteristics. Cole and 
Mehran (2008), on the other hand, look at executive characteristics and ownership structures but ignore performance and board characteristics. Examination of just a few characteristics in isolation ignores the fact that other non-measured characteristics may serve as complements or substitutes. Given the level of detail in the data we obtained from our survey, we are able to include a wide list of determinants which are expected to explain executive compensation. In addition to performance and board characteristics, we include executive characteristics such as ownership, education, executive position, and tenure. Finally, we include an indicator variable for the quality of the bonus plan as noted below. To our knowledge, this study is the most comprehensive study examining the determinants of executive compensation in privately held firms so far.

Previous studies that explore the pay to performance relation assume that the quality of compensation contracts is identical across executives. In contrast, we have detailed information on the design of bonus plans that allows us to rank them based on four unique characteristics. First, we consider bonus plans that rely on more than just one performance measure to be of higher quality than bonus plans that rely on only one performance measure. For example, Feltham and Xie (1994) argue that that most performance measures are incomplete or imperfect representations of the economic consequences of management actions. They recommend the use of more than just one performance measure; unless the performance measure is perfectly congruent and noiseless. Second, bonus plans that specifically consider the impact of both transitory items and changes in accounting policies on the performance measures adopted are believed to be of higher quality than bonus plans that ignore these issues. Third, Murphy (2000) find that income smoothing is prevalent in companies using internal standards (e.g. budget or last year's financial results), but not in companies using external standards. Thus, bonus plans based on external standards are considered to be of higher quality than bonus plans that rely on internal performance standards. Finally, Healy (1985) and Holmstrom and Milgrom (1987) suggest that the pay to performance structure is linear since it mitigates the incentive to manage the performance measure. Thus, linear bonus plans with no cap or floor are considered to be of higher quality than 
other bonus plans. In conclusion, we conjecture that bonus plans that include the above features are better designed and more accurately capture value creation. Such bonus plans should improve the pay to performance relation as well. Murphy (1999) argues that more research is required to better understand the design of accounting-based bonuses. By carefully studying the design of each bonus plan, as outlined above, we believe that we meet this request.

Most studies on executive compensation are based on either UK or US data. A comparison of the Danish and the UK and the US institutional settings reveals several differences that may affect what determine executive compensation. First, Firth et al. (1996) argue that Scandinavian countries (including Denmark) generally have a low variability in wage levels compared to other European countries and the US. ${ }^{1}$ Further, they conjecture that the lack of large differences in pay levels in the Scandinavian countries may be due to the state welfare philosophy, its tax system and the power of the trade unions. The low variability in compensation suggests that performance related pay is less frequently used or the resulting payoffs are small in magnitude. Second, the institutional setting in Denmark is characterised by a small open economy with a relationshiporiented corporate governance system, i.e. insider oriented (Eriksson and Lausten, 2000). This tends to reduce the information asymmetry and therefore the need for performance related pay. Third, Pedersen and Thomsen (1996) document that the existence of dual stock classes in Denmark is related to a higher level of shareholder concentration than in the UK and the US. The high level of ownership concentration leads us to believe that shareholders' monitoring of management plays a larger role in Denmark than in the UK and the US. We conjecture that the monitoring mechanism will reduce the need for performance related pay. Fourth, Denmark has a two-tier board structure as opposed to the one-tier board structure in the UK and the US. Fourth, in Denmark CEOs are allowed to serve on the supervisory board but not as board chairman. This is in contrast to for example the UK and the US, where CEOs are also allowed to serve as the board

\footnotetext{
${ }^{1}$ It is important to stress that the Nordic countries including Denmark, Finland, Norway and Sweden, are similar in terms of GDP, growth in GDP and inhabitants. Iceland is significantly smaller based on these criteria.
} 
chairman. These differences imply different board compositions across countries. For example, it is arguably less common to find an executive on a Danish board. Fifth, the degree to which an executive can influence board members is most likely smaller in Denmark than in the UK and the US, where executives also serve as board chairmen. In summary, we conjecture that the institutional differences may impact what determine variations in executive compensation in privately held firms in Denmark.

Since compensation data are not publicly available in Denmark, we collected the data through a questionnaire. Eventually 191 respondents completed the questionnaire. However, some respondents did not fill in the questionnaire in full leaving a final sample of 125 observations. Our data on compensation include insightful information on the various components of executives' compensation contracts.

Our results provide some interesting insights as to what explains executives' compensation in privately held firms. In line with our predictions we find that the pay to performance relation is weak. Board size and ownership concentration are the only corporate governance characteristics that explain variations in executive compensation. Executive characteristics like skills (size), executive position and educational attainment all explain variations in executive compensation. Finally, we do not find a stronger pay to performance relation in firms with better designed bonus plans.

The remainder of this paper is organised as follows. The next section develops our research hypotheses. In the third section the sample is described followed by a section outlining the research design. The descriptive statistics are provided in the fifth section, followed by the empirical results and robustness checks. Conclusions and suggestions for future research appear in the final section. 


\section{Research hypotheses}

The compensation literature has expanded considerably over the last decade with an increasing number of studies trying to explain the level of compensation. In the following, we list a number of determinants that are likely to elucidate the cross-sectional variation in executive compensation.

\section{Pay to Performance relation}

Compensation is often seen as an instrument to align managerial interests (agents) with those of the shareholders (principals). The basic idea is to reward executives according to their performance. A vast number of studies have explored the pay to performance relation. In their seminal work Jensen and Murphy (1990) find that executive wealth in the US increases by $\$ 3.25$ for every $\$ 1,000$ increase in shareholder wealth. They conclude that this increase is low. Hall and Liebman (1998) find a strong link between the fortunes of US executives and the fortunes of the firms they manage.

Studies outside the US document that the pay to performance relation is low or even negative. Zhou (1999) compares the pay to performance relationship in the US and Canada. He finds that the pay to performance sensitivity is considerably higher in the US than in Canada. Conyon and Murphy (2000) find that the US executive receives $4.18 \%$ of any increase in shareholder wealth compared to $2.33 \%$ in the UK. A range of other UK studies also find positive but low pay to performance relations [Main et al. (1996), McKnight and Tomkins (1999), and Buck et al (2003)]. Brunello et al. (2001) on Italian data, Eriksson and Lausten (2000) on Danish data, Kato and Kubo (2003) on Japanese data and Kato et al. (2004) on Korean data all find positive but low pay to performance relations. Analysing a sample of Norwegian and Swedish firms, Randhøy and Nielsen (2002) do not find any link between pay and performance. Fernandes (2008) reaches a similar conclusion based on a sample of Portuguese firms. Finally, based on Dutch firms Duffheus and Kabir (2007) find a negative pay to performance relation. Thus, although most studies find a positive pay to performance relation it seems low in most cases. 
We conjecture that the pay to performance relation is weak based on data from Danish privately held firms. First, while privately held firms are often characterised by high levels of ownership concentration publicly traded firms have more diffused ownership structures. Thus, owners in privately held firms have better incentives to monitor the actions of the executives reducing the need for performance related compensation. Second, as mentioned in the introduction, factors such as the relationship-oriented corporate governance system and the low variability in wage levels in Denmark, compared to other European countries and the US, reduce the use of performance related pay. Third, privately held firms are typically small relative to publicly traded firms and most likely less sophisticated in using performance related pay. Finally, Ball and Shivakumar (2005) find that earnings is a relatively more noisy measure of performance in privately held firms than in publicly traded firms. If earnings is a noisy measure of performance the pay to performance relation will be distorted. All these factors are expected to weaken the pay to performance relation for privately held firms.

Hypothesis 1: There is a positive but weak relation between firm performance and executive compensation

\section{Corporate Governance characteristics}

The literature on corporate governance examines the efficiency of alternative board characteristics and ownership structures. For example, Jensen (1993) argues that supervisory boards are ineffective when there is little equity ownership represented on the board, the CEO and the board chair is the same person, and if the CEO determines the agenda and the material presented at board meetings. In the compensation literature corporate governance parameters have been used to explain variations in executive compensation. The basic idea is that inefficient corporate governance structures lead to excessive executive compensation. Core et al (1999) argue that no board characteristics and ownership structure would be significant in a setting where the 
executive's compensation contract specifies the level of compensation as function of the firm's performance in order to maximise firm value; conditional of the firm's informational environment and its demand for high quality executives. In this setting the board characteristics and ownership structure are simply 'noisy measures' of the same variables that determine executive compensation. However, in a setting where the compensation contract is not optimally designed, board characteristics and ownership structures are expected to affect the level of executive compensation. We explore different board characteristics and ownership structures that may affect the level of executive compensation.

Large supervisory boards are likely to have a wider level of expertise. However, they can become so unwieldy that they become ineffective in monitoring executives (Jensen, 1993). Jensen (1993) points out that when the board exceeds seven or eight members they are less likely to function effectively and are easier for an executive to control. Yermack (1996) demonstrates how smaller boards are effective in enhancing firm performance. Holthausen and Larcker (1993) and Core et al. (1999) find that large US boards are associated with excessive compensation. These results are obtained in a one-tier board structure setting. Since Denmark (and other Scandinavian countries) has a two-tier board structure the impact of the supervisory board may be different. However, Randhøy and Nielsen (2002) find similar results based on Norwegian and Swedish data. Thus, it indicates that there exists a positive relation between board size and the level of compensation in settings characterised by both a one-tier and a two-tier board system.

Hypothesis 2a: There is a positive relation between board size and executive compensation

Pfeffer (1981) argues that inside board members are more loyal to management. This implies that executives can exert relatively more influence over inside board members as opposed to outside board members. However, empirical findings by Core (1999) indicate that the relation between 
executive compensation and percentage of inside directors is negative. ${ }^{2}$ These results suggest that theory and empirical evidence are not in line. We examine if there is a positive relation between the percentage of inside board members and the level of executive compensation in privately held firms.

Hypothesis $2 b$ : There is a positive relation between the percentage of inside board members and executive compensation

Finkelstein and D'Aveni (1994) argue that a separate management structure will lead to greater degree of independence to the board in various issues related to monitoring managerial performance. It is expected that boards that have an independent chairman will be more effective in designing a compensation contract and monitoring the performance of management. This also implies that if the executive serves on the board, the independency of the board is reduced and it may affect, among other things, the design of an effective compensation contract. Core et al (1999) and lyengar et al. (2005) confirm these predictions. They find that compensation levels are higher in firms where the executive is also the board chair. On the other hand, Angbazo and Narayanan (1997) and Conyon (1997) find no such relation in their study of US and British firms, respectively. In Denmark, an executive is not allowed to serve as chairman of the board. However, an executive may serve as an ordinary board member. Even though the power of an executive as an ordinary board member is not equivalent to the power of the board chairman, we conjecture that the board's independence is reduced to an extent that may lead to inefficient compensation contracts. This implies that compensation contracts may compensate executives excessively.

Hypothesis 2c: The level of compensation is higher in firms where the executive also serves on the board

\footnotetext{
${ }^{2}$ Lambert et al. (1993) and Boyd (1994) obtain similar results.
} 
As noted in the introduction, the level of ownership concentration tends to be high in privately held firms as opposed to the often diffuse ownership structure of publicly traded firms. This provides owners in privately held firms with better economic incentives to monitor the actions taken by executives (Fama and Jensen, 1983). They also have better access to executives. These factors reduce the need for performance related pay. Several studies confirm this prediction. For example, Core et al. (1999) and Haid and Yurtoglus (2006) find a negative association between the level of ownership concentration and executive compensation based on US and German data, respectively. We also examine if the association between ownership concentration and executive compensation is negative in privately held firms.

Hypothesis 2d: The level of executive compensation is lower in firms with a high level of ownership concentration

\section{Executive characteristics}

We explore the impact of executive characteristics on the level of executive compensation. We investigate five types of executive characteristics that may affect the level of executive compensation (hypotheses 3a-3e).

One source of executive power is long tenure (Hill and Phan, 1991). Long tenure increases the chances that executives influence the selection of (some) board members. Further, long tenure also ensures stronger relationships with board members. Thus, tenure may explain the level of executive compensation. The empirical evidence on the tenure hypothesis is mixed. Finkelstein and Hambrick (1989) find a curve-linear relation between executive tenure and compensation. Attaway (2000) finds a positive association. O'Reilly et al. (1988), on the other hand, find a negative association. Finally, Randhøy and Nielsen (2002) find no association between tenure and the level of pay. Thus, previous empirical studies do not provide conclusive evidence in support for 
the tenure hypothesis. We examine the impact of tenure on executive compensation in privately held firms.

Hypothesis 3a: There is a positive association between executive tenure and executive compensation

Larger and more complex organisations are more difficult to manage and therefore also attract better performing executives. For example, Jensen and Meckling (1976) theorise that the largest firms hire the better performing executives to maximise their productivity. Oetomo and Swan (2003) find that firm size is a partial proxy for managerial ability. Previous studies provide strong evidence in favour of the size hypothesis. Kaplan (1994) on Japanese data, Conyon and Murphy (2000) on UK and US data, Brunello et al (2001) on Italian data, Zhou (2000) on Canadian data, and Haid and Yurtoglu (2006) on German data all find a positive and significant association between executives' pay and firm size. In fact, in a meta-analysis Tosi et al. (2000) conclude that firm size accounts for more than $40 \%$ of the variance in executive pay while firm performance accounts for less than $5 \%$. We, therefore, expect a positive association between executives' pay and firm size.

Hypothesis $3 b$ : There is a positive relation between firm size and executive compensation

The CEO has the overall responsibility of a firm's performance. This also explains the number of papers examining the relation between performance and CEO compensation. Although other executives (non-CEOs) such as the chief financial officer (CFO) and the chief developing officer are responsible for the performance of the company too, they will not have the same opportunities to affect the business as the CEO. Further, the level of responsibility is not the same as for the CEO. Thus, the pay to performance relation is expected to vary across different hierarchical levels. Murphy (1985) finds no differences in the pay to performance relation between CEOs, presidents 
and vice presidents. Ericsson and Lausten (2000), on the other hand, find small differences in the pay to performance relation across different management levels based on Danish data. We conjecture that the pay to performance relation is weaker for non-CEOs than for CEOs.

Hypothesis 3c: The pay to performance relation is weaker for non-CEOs than for CEOs

Companies characterised by a high level of managerial ownership already align the interests of the principal and agent. Executives who own shares in their companies have, therefore, a lesser need for direct compensation as they receive dividends and capital gains from their shareholdings. Lower direct compensation may also signal fiscal responsibility by the executive-owners (Ramaswamy et al., 2000). Hall and Liebman (1998) and Banghøj and Plenborg (2008) document that managerial ownership is more important than stock options and cash pay as a managerial incentive. Thus, in a Danish setting, where managerial ownership is more common than in the UK and the US [Conyon and Murphy (2000) and Gabrielsen et al. (2002)], we believe that it is important to include executives' stock holdings when explaining the level of executive compensation. A number of studies examine the association between managerial ownership and the level of executive compensation. Core et al (1999) find that executive compensation in the US is a decreasing function of the executive's ownership stake. Randhøy and Nielsen (2002) on both Norwegian and Swedish data, and Cheng and Firth (2005) on Hong Kong data find similar results.

Hypothesis 3d: Executive compensation is a decreasing function of the executive's ownership stake

There are reasons to believe that executive compensation may be a function of educational skills. Based on publicly traded data Chung and Pruitt (1996) find a positive, although insignificant, association between educational attainment and executive pay. Cole and Mehran (2008) find a positive and significant association between the level of education and executive pay in privately 
held firms. This indicates that there exists a positive association between educational attainment and executive compensation.

Hypothesis 3e: There is a positive relation between educational attainment and executive compensation

\section{Quality of bonus plan}

To our knowledge previous studies that explore the pay to performance relation assume that the quality of bonus plans is identical across executives. We challenge this view by arguing that the pay to performance relation is a function of the quality of the bonus plan. Inspired by Murphy (1999) we list four areas that need to be addressed when designing a bonus plan. First, the board needs to decide on an appropriate performance measure. Feltham and Xie (1994) point out that the literature has paid only limited attention to the fact that performance measures are frequently incomplete or imperfect representations of the economic consequences of the manager's action. Thus, the choice of performance measure is not obvious. Feltham and Xie recommend the use of only one performance measure if, and only if, the performance measure is perfectly congruent and noiseless. In other cases, more than one performance measure is recommended. Gibbs et al (2007) find that firms use incentive systems of multiple performance measures as a response to flaws in available performance measures. Thus, bonus plans that tend to use more than just one performance measure is considered to be of higher quality.

Second, the literature on financial statement analysis [(see e.g. Bernstein and Wild (1998) and Penman (2007)] suggests that one dollar of earnings is valued differently by shareholders. Earnings generated from the core business (permanent earnings) are regarded as more valuable than earnings based on transitory items (i.e. the impact of changes in accounting policies and unusual accounting items recognised as part of core earnings). Thus, bonus plans that explicitly 
address the consequences of unusual items and changes in accounting policies on earnings are considered to be of higher quality than other contracts.

Third, Murphy (2000) finds support for the use of external standards. He finds that income smoothing is prevalent in companies using internal standards (e.g. budgets and last year's result), but not in companies using external standards. This suggests that bonus plans based on external standards better capture the value contribution of executives. They are, therefore, considered to be of higher quality than bonus plans that rely on internal performance standards.

Finally, Holmstrom and Milgrom (1987) suggest that the pay to performance structure should be linear since it mitigates the incentive to manage the performance measure. Non-linear bonus plans provide the executives with an incentive to manage earnings. For example, if the year-to-date performance indicates that annual performance will exceed that required to achieve the bonus cap, executives will either withhold effort or 'move' current earnings to future periods (Healy, 1985). Thus, linear bonus plans with no cap or floor are considered to be of higher quality than other bonus plans. In summary, a well designed bonus plan is expected to capture the actual value creation better than a poorly designed bonus plan and should, consequently, improve the pay to performance relation.

Hypothesis 4: The positive pay to performance relation is stronger for better designed bonus plans

\section{Sample}

According to Danish accounting legislation privately held firms need only provide limited information on executive compensation. Due to the lack of data, we made a questionnaire survey in the spring of 2007 in order to examine current practice for compensation among privately held 
firms. The questionnaire focuses on the technical aspects of accounting based bonus plans. ${ }^{3}$ To increase the likelihood that all relevant questions were included and that the questions were easily understood, six persons, four advisors and two executives, pre-tested the questionnaire. In addition, the questionnaire was tested by our colleagues. As a result of this pilot-project, we made some rephrasing, added a few extra options for answering selected questions and expanded the questionnaire with further relevant questions.

The study is based on firms belonging to accounting class $C$ (midsize and large firms). These firms are more representative for the Danish business community than publicly traded firms. It is also considered more likely that firms in class $\mathrm{C}$ would fill in the questionnaire than firms in class $\mathrm{A}$ and B (small firms), respectively. Organisations, firms from the public sector and funds are not included in the sample, as the incentive structure for those firms is different from other privately held firms. Based on the above criteria 2,127 firms were selected from the database Soliditet. ${ }^{4} 500$ of those were chosen randomly. ${ }^{5}$ Each of the 500 firms was contacted by phone in order to obtain e-mail addresses for every executive. If the executive board consisted of more than one member (CEO) all executives received the questionnaire. The outcome was 574 possible respondents. On April 27, 2007 the questionnaire was mailed to the respondents via an e-mail service made available by Defgo. On May 21, 219 had opened the questionnaire and of those 191 respondents filled it in. This corresponds to a response rate of $33 \%$, which is satisfactory for questionnaires (Petersen and Plenborg, 2007). Unfortunately, not all executives filled in the questionnaire entirely, reducing sample size further. Thus, our tests are based on a sample of 125 observations. ${ }^{6}$ The accounting data used in our study is retrieved from Soliditet.

\footnotetext{
${ }^{3} \mathrm{~A}$ copy of the questionnaire may be obtained by request to the authors.

${ }^{4}$ Soliditet is a database containing information on firm specific data such as management board members, members of the supervisory board and corporate structure. Furthermore the database contains information from financial reports and ratios based on accounting information. Soliditet is part of Dun \& Bradstreet.

${ }^{5}$ This took place in a random procedure in Microsoft Excel.

${ }^{6}$ In cases where we have more than 125 observations available we repeat the test. These tests produce results similar to the ones reported in this study (not reported).
} 
To clarify if firms, which filled in the questionnaire, have specific characteristics (selection bias), we compared the respondent firms with the ones that did not reply. Data needed to do so were obtained from Soliditet, Firms that did not respond to the questionnaire had an average turnover of DKK 899 million versus DKK 863 million for firms that accepted to participate. Average total assets was DKK 617 million for firms that did not participate versus DKK 584 million for firms that filled in the questionnaire. This indicates that there is not a large difference between firms that participate and those that chose not to.

\section{Research design}

Agency theory posits simultaneous relations between performance and the level of pay (Anderson et al. 2000, 534). Anderson et al. (2000) find that when these simultaneous relations are ignored, the results are quite different from a simple one-stage least square regression. In order to take into account the simultaneity of performance and pay we run specifications using both a two-stage least squares approach and a three-stage least squares approach. ${ }^{7}$

The specifications adopted to analyse the determinants of executive compensation in privately held firms are listed below: ${ }^{8}$

In (executive compensation $)=\beta_{0}+\beta_{1}$ Performance $_{t}+\beta_{2}$ Performance $_{t-1}+\beta_{3}$ Size $+\beta_{4}$ Executive member of board $+\beta_{5}$ No. of board members $+\beta_{6}$ Insiders $+\beta_{7}$ OwnCon $+\beta_{8}$ CEO +

\footnotetext{
${ }^{7}$ Since both approaches yield similar results we only report results based on a two-stage least squares approach.

${ }^{8}$ Even though we apply a two-stage least squares approach we only report the results where executive compensation serves as the response variable.
} 
$\beta_{9}$ Performance ${ }^{*}$ CEO $+\beta_{10}$ Executive Ownership $+\beta_{11}$ Tenure $+\beta_{12}$ Education $+\beta_{13}$ Quality +

$\beta_{14}$ Performance* quality $+\beta_{15}$ Leverage $+\varepsilon_{i}$

Performance $=\alpha_{0}+\alpha_{1} \ln$ (executive compensation) $)_{i}+\alpha_{2}$ Size $+\alpha_{3}$ Leverage $+\alpha_{4}$ Industry $+\alpha_{5}$ Growth $+\varepsilon_{i}^{9}$

We have used industry and growth as additional instrumental variables along with size and leverage. Following the advice of Stock et al (2002), we examine whether weak instruments potentially are a problem in a given application by checking the first-stage F-statistic. In the specifications that we report first-stage F-statistic is approximately 12 in most specifications, which is above the recommended minimum level indicating strong instrumental variables.

\section{Endogenous variables}

In (executive compensation) is defined as the natural logarithm of total salary plus bonus. Our survey data reveal that 35 executives are awarded stock options too. Due to data limitations we are not able to estimate the value of the awarded stock options. Thus, we cannot include them as part of compensation. Previous studies examining data from privately held firms ignore the impact of stock options (see for example Ke et al., 1999 and Cole and Mehran, 2008). We are able to distinguish executives who receive stock options in addition to bonus from executives who receive salary and bonus only. This allows us to run different types of robustness checks. First, we run a regression (equation 1) excluding executives who receive stock options. Second, we include stock options as an explanatory variable in model (1). If the coefficient of stock options is not statistically different from zero, it indicates that stock options are equally distributed across respondents (and only the intercept will be affected by the omission of stock options).

\footnotetext{
${ }^{9}$ We have examined the impact of other explanatory variables such as ownership concentration and managerial ownership. However, the results remain similar to the simple performance equation (2).
} 
We use three proxies for firm performance. Return on assets, defined as EBIT divided by total assets, return on equity, defined as net earnings divided by shareholders equity, and net earnings.

\section{Exogenous variables}

Based on our hypotheses we include board-, ownership-, executive-, and quality-specific variables as explanatory variables. Included as board variables are board size, defined as the number of board members, percentage of inside board members, and a dummy variable that equals 1 if the executive also serves on the board and 0 otherwise. Ownership concentration is defined as the percentage of shares owned by the largest shareholder. ${ }^{10}$ As executive specific variables we include tenure defined as the number of years that the executive has hold current position, size, measured as the natural logarithm of total assets, a dummy variable that equals 1 if the executive is CEO and 0 otherwise, a dummy variable that equals 1 if the executive holds stocks in his firm and 0 otherwise, and executive education as measured by dummy variables indicating the executive's highest educational attainment (from primary and lower-secondary school to a graduate degree).

Our quality measure of bonus plans consists of four indicators. Each indicator receives a value between 0 and 1, where 1 indicates the highest quality. The first quality indicator is the number of performance measures applied in each bonus plan. Bonus plans applying one or two performance measures obtain a score of 0.33 and 0.67 , respectively. Bonus plans that apply three or more performance measures receive a score of 1 . The second quality indicator is based on the level of noise in each performance measure. The information from the questionnaire allows us to rank each bonus plan based on the degree to which it considers the impact of transitory items and changes in accounting policies on the performance measures adopted. For example, if the bonus plan takes into account both transitory items and changes in accounting policies the bonus plan

\footnotetext{
${ }^{10}$ Alternative definitions of ownership concentration are also applied.
} 
receives a score of 1 . The third indicator considers the quality of the performance standard. Bonus plans relying on an internal (external) standard receive a score of $0.33(1.0)$. Bonus plans that rely on both an internal and external standard receive a score of 0.66 . The final indicator is based on the pay to performance structure in each compensation contract. The questionnaire allows us to divide the bonus plans into twenty incentive zones depending on the cap and floor used. An incentive zone with no cap or floor receives a score of 1 . A bonus plan with no incentive zone receives a score of 0 . A factor analysis suggests that the four indicators load on the same maximum-likelihood factor. Thus, we also create a quality index based on the average score of the four indicators. Each bonus plan is ranked from 0 to 1 based on the average score.

To rule out alternative explanations to our findings we include leverage and regulated industry as control variables. Lippert and More (1994) and Lippert and Porter (1997) find that executive compensation is higher for firms with higher risk (measured as stock volatility). Since stock prices are not observable for privately held firms, we adopt the level of debt to assets ratio as a proxy for risk. Murphy (1999) finds that the level of compensation is lower for regulated industries such as utilities. Thus, we include a dummy variable that equals 1 for regulated industries and 0 otherwise. ${ }^{11}$ Finally, $\varepsilon_{\mathrm{i}}$ is a normally distributed error term.

\section{Alternative specification}

As shown in Lambert and Larcker (1987) and Boschen et al. (2003) the relation between compensation and performance is complicated. They, therefore, suggest employing a first difference model in the line with the following specification (3):

$\Delta C_{t}=\beta_{0}+\beta_{1}\left[X_{t}-E\left(X_{t}\right)\right]+\beta_{2}$ ScaleQuality $+\beta_{3}\left[X_{t}-E\left(X_{t}\right)\right] *$ ScaleQuality $+\beta_{4}$ Size $+\varepsilon$

\footnotetext{
${ }^{11}$ There are only four regulated (telecom, utilities, financial institutions and transportation) companies included in the sample and they do not affect the results reported. We therefore report the results without including the industry dummy.
} 
Where $\mathrm{C}$ is compensation, $\mathrm{X}$ is an accounting performance measure, $\mathrm{E}$ is the expectation operator, and ScaleQuality is a quality index that ranks each bonus plan based on four quality indicators. Although the (first-difference) model does not explicitly estimate the long-run response of compensation to unexpected performance, the structure of the model implies that increases in compensation from unexpected performance remain permanently in the level of compensation. In order to relax this constraint we also run the following specification (4):

$C_{t}=\beta_{0}+\alpha C_{t-1}+\beta_{1}\left[X_{t}-E\left(X_{t}\right)\right]+\beta_{2}$ ScaleQuality $+\beta_{3}\left[X_{t}-E\left(X_{t}\right)\right]^{\star}$ ScaleQuality $+\beta_{4}$ Size $+\varepsilon$

This specification allows Ct-1 to be positive, but less than one.12 In (3) we assume that accounting performance follows a random walk. Watts and Leftwich (1977) find that the random walk model is a good description of the process generating earnings in general, and for individual firms.

\section{Descriptive statistics}

The descriptive statistics are reported in table 1 . The average salary including bonus is DKK 1.9 million. Firms included in the sample generate an average return on assets of $7.8 \%$. The average (median) return on equity equals $23.4 \%$ (15.1\%) which reflects that leverage affects shareholders' return positively.

[Insert table 1 about here]

The descriptive statistics on the corporate governance variables show that $34 \%$ of the executives also hold a position on the supervisory board. Core et al. (1999) find that $76 \%$ of the CEOs also serve as chairman of the board. Thus, in a one-tier system like the US it is common for the executive to serve on the board. In a two-tier system like the Danish CEOs are not allowed to

\footnotetext{
${ }^{12}$ It is important to stress that by using a first-difference model we do not need to control for the same factors as in a level-specification. Thus, in addition to the quality index (interaction term) we only control for size which is in line with Boschen et al. (2003).
} 
serve as chairman of the board. The average size of the supervisory board is 6.0 . This is generally lower than found in publicly traded firms. Core et al (1999) find that the average board size of publicly traded US firms is 13. Randhøy and Nielsen (2002) find that the average board size for publicly traded Norwegian and Swedish firms is 7.2 . Further, on average $66 \%$ of the board members are classified as insiders. This indicates that privately held firms more frequently rely on insiders than publicly traded firms. For example, Core et al. find that only $32 \%$ of the board members in their sample are classified as insiders. The average ownership concentration is $71 \%$ which is considerably higher than found in studies applying publicly traded firms. This confirms that privately held firms have a higher level of ownership concentration than publicly traded firms.

The descriptive statistics on the executive characteristics reveal that the average tenure is 5.3 years. The average age of the executive is 49.3 years. Cole and Mehran (2008) find that the average age of executives in privately held US firms is almost 50 years. Approximately $70 \%$ of the executives in our sample hold the position of CEO. On average $36 \%$ of the executives own stocks in their firm and more than half of the executives hold a graduate degree. Cole and Mehran (2008) find that the executives included in their sample have a lower degree of education than executives in our sample. Further, most of the US executives own stocks in their firm. The differences between the executive characteristics found in Cole and Mehran (2008) and in our sample are most likely due to differences in firm size. For example, the average turnover for the privately held US firms in Mehran (2008) is \$ 2.1 million. In our sample, the average turnover is \$ 169 million (not reported).

Finally, the descriptive statistics on the quality of the bonus plans reveal that many bonus plans do not consider the impact of transitory items and changes in accounting policies on performance measures. On the other hand, more than half of the bonus plans include three or more performance measures. Descriptive statistics on the quality index based on the average score of the four indicators show that no bonus plan meets the criteria for 'best practice'; i.e. obtaining a 
score of 1 (the highest score is 0.75 ). Further, the quality index score does not seem to be clustered around a certain value but is normally distributed around 0.44 . This increases the likelihood that the quality index may explain differences in the pay to performance relation across executives.

[Insert table 2 about here]

The correlations reported in table 2 provide preliminary evidence on some of the hypotheses. First, performance, as expressed by ROA, does not seem to explain the variation in executive compensation. The correlation coefficients on $\mathrm{ROA}_{t}$ and $\mathrm{ROA}_{\mathrm{t}-1}$ are close to zero and insignificant. Second, the number of board members seems to be positively correlated with level of compensation. The correlation coefficient is significant at the $1 \%$ level. The correlation coefficients on the other corporate governance characteristics remain close to zero and insignificant. Third, size is, in line with previous studies, highly correlated with level of compensation and significant at the $1 \%$ level. The executive's educational attainment also seems to explain the level of compensation. The coefficient is positive and significant at the $5 \%$ level. Further, CEOs seem to receive a higher level of compensation than other executives. Other executive characteristics such as tenure and executives that own stocks in their firm do not seem to explain the variation in executive compensation. Finally, the correlation coefficient between the quality index and executive compensation is close to zero and insignificant. Some of the independent variables are correlated at conventional significance levels which may indicate the presence of multicollinearity. Thus, as part of the robustness check we examine whether the reported results are affected by the presence of multicollinearity.

\section{Empirical results}

The results of our tests of the different hypotheses are reported in table 3. Tosi et al. (2000) conclude that firm size accounts for more than $40 \%$ of the variance in executive pay. Thus, even 
though we define size as a proxy for executive skills, we include the variable in all our tests. In table 3, panel A executive compensation is regressed on $\mathrm{ROA}_{\mathrm{t}}$. The coefficient is positive as expected but not significantly different from zero. In line with our hypothesis we find a positive but weak pay to performance relation. ${ }^{13}$ The coefficient on size is positive and significant at the $1 \%$ level, which confirms that size explains a significant part of the variations in executive compensation. A coefficient of 0.19 implies that every time firm size doubles compensation increases by $14 \%$. The coefficient on leverage is negative but not significantly different from zero. This result contradicts the finding of Lippert and Porter (1997), who find that executive compensation is higher for firms with higher risk. One explanation may be that firms with high financial leverage have incentives to monitor the cash (out)flows more closely and thereby also the cash compensation to executives.

[Insert table 3 about here]

In table 3, panel B we examine if executive compensation is a function of past-year performance. Even though the coefficient on $\mathrm{ROA}_{t-1}$ is positive and higher than the coefficient on $\mathrm{ROA}_{t}$ it remains insignificant. However, it indicates that executive compensation to a larger degree is determined by past-year performance than current-year performance.

In table 3, panel $\mathrm{C}$ we examine the association between corporate governance characteristics and executive compensation. In line with Core et al. (1999) and Randhøy and Nielsen (2002) we find that large supervisory boards are associated with excessive executive compensation. Based on the coefficient we can infer that for every additional board member compensation will increase by nearly $5 \%$. On the other hand, the coefficients on the percentage of inside board members, executive ownership, and ownership concentration are all insignificant. This indicates that neither

\footnotetext{
${ }^{13}$ In the alternative specification where ROA serves as the response variable the coefficient on executive compensation remains close to zero and insignificant. This indicates that the performance to pay relation is also weak.
} 
of these corporate governance characteristics explains the variation in executive compensation. The coefficients on the variables reported in table 3, panel A remain qualitatively the same and with similar significance levels.

The coefficients on executive characteristics are reported in table 3, panel $\mathrm{D}$. The coefficient on the CEO indicator reflects that the CEOs level of compensation is significantly higher than other executives' level of compensation. On average, CEOs earn 34\% more than other executives. Although the pay to performance relation is stronger for CEOs than for other executives it is not significant. While the coefficient on $\mathrm{ROA}_{t}$ is $1.04(0.58+0.46)$ for CEOs it is 0.58 for other executives. An F-test (not reported) reveals that the coefficient on $\mathrm{ROA}_{t}$ for CEOs remains insignificant. Thus, despite the difference in the coefficients on $\mathrm{ROA}_{t}$ across executives the performance measure does not explain the variation in executive compensation.

In line with the results of Cole and Mehran (2008) the coefficient on executives' educational attainment is positive and significant at conventional levels. In fact, for every improvement in educational attainment (on a scale from 1 to 7 ) we find that executives earn $5.7 \%$ more. It supports the extensive literature that examines the impact of education on earnings. For example, Green and Riddell (2001) find that each additional year of education raises earnings by approximately $8 \%$.

Contrary to Core et al. (1999) and Randhøy and Nielsen (2002) we do not find that executive compensation is a decreasing function of the executive's ownership stake. The coefficient on executive ownership is slightly positive but insignificant. One explanation for this finding may be that performance related pay is less common in privately held firms resulting in a fairly constant level of compensation across different executives' ownership stakes. The coefficient on tenure also remains insignificant indicating that this variable does not explain the variation in executive compensation. 
The quality of the bonus plan is the final category of explanatory variables that we examine. We conjecture that the pay to performance relation is stronger for better designed bonus plans. ${ }^{14}$ As shown in table 3, panel $E$ the interaction term between performance and the quality indicator is positive and insignificant. Thus, our measure of quality does not improve the pay to performance relation. This may be due to a quality measure that suffers from biases or that the board chose an optimal contract given the firm's informational environment and its demand for high quality executives. However, the results may also be influenced by the modest number of observations available in this specification. In the robustness check below we explore this finding in further details.

As a final test we include all explanatory variables in model $(1) .{ }^{15}$ The results reported in table 3 , panel F generally support the findings listed above. The coefficients on firm size, board size, educational attainment, and CEO versus other executives remain positive and significant at conventional levels. In addition, ownership concentration seems to explain variations in executive compensation as well. However, opposite to our expectation the coefficient is positive indicating that executive compensation improves as ownership concentration increases. We elaborate further on this finding below.

\footnotetext{
${ }^{14}$ Please note, that only firms with bonus plans are included in the test. This more than halved the sample size.

${ }^{15}$ Due to data restrictions we exclude the quality measure of bonus plans from our test.
} 


\section{Robustness checks}

In order to further strengthening our results we conduct a range of additional tests. First, we use return on equity and net earnings, respectively, as proxies for performance. In neither of these specifications do the alternative performance measures explain the level of compensation. This finding supports that performance does not explain variations in executive compensation.

We also examine if the pay to performance relation is non-linear. One may argue that the pay to performance relation is only positive for firms reporting positive ROA. The basic idea is that executives still receive a salary even when ROA is negative. To examine if this holds true we create an indicator variable that equals one when ROA is positive and zero otherwise. We multiply the indicator variable with the performance to explore if the pay to performance relation is nonlinear. However, the coefficient on the interaction term remains insignificant indicating that the pay to performance relation is similar for firms generating both positive and negative ROAs.

In addition, we use In (sales) and In (employees) as proxies for size. The coefficients on both proxies remain positive and significant at the 1\% level. Further, the coefficients and significance levels of the other variables remain qualitatively unchanged.

We examine alternative specifications of the ownership concentration variable. First, we define ownership concentration as the sum of the three largest shareholders. The coefficient on this alternative ownership specification is positive and significant at the $5 \%$ level. This supports that ownership concentration explains variations in executive compensation. Second, we examine if the type of owners impact the level of executive compensation. Specifically, we make a distinction between institutional -, firm-/family- ${ }^{16}$, foundation-, and state ownership. Interestingly, only the coefficient on firm/family ownership is positive and significant. This indicates that the result found in

\footnotetext{
${ }^{16}$ The way that ownership data is reported in Denmark makes it difficult to make a distinction between family- and firm ownership, respectively. Thus, we combine the two types of ownership into one ownership variable.
} 
table $3(F)$ is primarily driven by firm/family ownership. Firm/family owned businesses seem more generous with their compensation to executives than firms owned by institutional investors, foundations and the state.

Our quality indicator of the bonus plans did not improve the pay to performance relation. One explanation may be that we add four quality indicators that provide different types of information. Thus, we examine how each of the quality indicators' influences the pay to performance relation. The results are reported in table 4.

[Insert table 4 about here]

As can be seen from table 4, the coefficients on the interaction terms take different signs. While the coefficient on performance standards is negative the coefficients on the other three quality indicators are positive. Thus, the quality indicators seem to provide different information on the pay to performance relation. None of the coefficients are, however, significantly different from zero.

We also used an alternative indicator for the quality of the compensation contracts. The participants in our survey rated the compensation contract based on their perception of the quality of the compensation contract. We used that rating as an indicator of the overall quality of the compensation contract and created a new interaction term (ROA*rating). We conjecture that the pay to performance relation will be stronger for compensation contracts receiving a high rating. The coefficient on the interaction term remains close to zero and insignificant. Thus, our different proxies for quality do not improve the pay to performance relation.

As mentioned above, we cannot include stock options as part of executive compensation due to data limitations. However, we repeat our test excluding executives that receive stock options as part of their compensation. The results remain similar to the results based on the full sample. 
Finally, we also included stock options as an explanatory (indicator) variable in model (1). The coefficient on the stock options remains close to zero and insignificant. This indicates that stock options are equally distributed across respondents. We, therefore, believe that our results are robust even though we are not able to include the value of awarded stock options in the calculation of executives' compensation.

Since the relation between compensation and performance is complicated Lambert and Larcker (1987) and Boschen et al. (2003) suggest employing a first difference model in the line with specifications (2) and (3), respectively. In table 5 we report the results for these specifications. ${ }^{17}$

[Insert table 5 about here]

In line with the results reported in table 3 (and 4), performance does not explain the change in compensation. Size, on the other hand, remains an important determinant for executive compensation.

As noted above some of the independent variables are correlated at conventional significance levels which indicate the presence of multicollinearity. Consequently, we examine the robustness of the reported results by excluding one independent variable at a time. The results of the reduced model remain similar to the reported results based on the full model. This indicates that the reported findings are not affected by multicollinearity. In summary, the results from the different robustness checks support the statistics reported in table 3.

\section{Summary and conclusions}

This paper documents how four different categories of determinants affect executive compensation in privately held firms in Denmark. In line with our predictions we find that the pay to performance

\footnotetext{
${ }^{17}$ Due to missing observations we exclude the quality index.
} 
relation is weak. Corporate governance characteristics only vaguely explain determinants of executive compensation. Board size and ownership concentration are the only corporate governance characteristics that explain variations in executive compensation. On the other hand, we find that executive characteristics like skills (size), executive position and educational level are important in explaining variations in executive compensation. Finally, as a novelty we allow the quality of the bonus plan to vary across executives. Contrary to our expectations we do not find a stronger pay to performance relation in firms with better designed bonus plans.

Our study confirms that research on privately held firms that is based on an institutional setting that deviates from the UK and the US, respectively, offers insightful results. First, the weak pay to performance relation is most likely explained by the fact that a) performance related pay is less common in privately held firms in Denmark and b) earnings is a relatively more noisy measure of performance in privately held firms than in publicly traded firms (Ball and Shivakumar, 2005). Second, we only find one board characteristic that explains variations in executive compensation. Other studies that rely on publicly traded firms find evidence of a significant association between many of the board characteristics and CEO compensation. One explanation for our finding may be that board characteristics in privately held firms simply serve as 'noisy measures' of the same variables that determine executive compensation. Differences in the institutional settings may serve as an alternative explanation. For example, in contrast to Core et al. (1999) we do not find that the level of executive compensation is higher in firms where the executive also serves on the board. This is most likely due to the fact that executives in Denmark are not allowed to serve as chairman of the supervisory board. Third, the executive's educational attainment proves to be an important explanatory variable in explaining variations in executive compensation. To our knowledge only a few compensation studies have included executive characteristics like educational attainment when explaining variations in executive compensation. 
Finally, the inability to explain variations in the pay to performance relation based on our quality index is surprising. In the literature there are strong arguments in favour of including the quality index. For example, it seems obvious that bonus plans that consider the impact of transitory items (for example restructuring charges) and changes in accounting policies on the adopted performance measures are of better quality than bonus plans that ignore these effects. One explanation for this surprising finding may be that the underlying pay to performance relation is weak. Another explanation may be that the quality index is not properly specified. For example, we regard bonus plans that include three or more performance measures as better than bonus plans that rely on only one or two performance measures. It is not clear whether this distinction is appropriate. Obviously, the limited number of observations in the specifications including the quality index also reduces the chances of a significant coefficient on the quality index.

We believe that our study can be expanded in different ways. Future studies may examine whether the weak pay to performance relation identified in privately held firms is a result of an efficient corporate governance structure or a result of poorly designed compensation contract. Second, although the coefficient on our quality index remains insignificant we believe that a way to expand the study is to explore each compensation contract in further detail. Previous studies assume that the quality of the executive compensation contract is identical. Future studies may shed light on why some compensation contracts contain only one performance measure while other contracts include three or more performance measures. Further, why do some contracts ignore the impact of transitory items on performance measures adopted while other contracts carefully consider these items? And why is the pay to performance relation not stronger for firms that carefully consider the impact of transitory items? These issues ought to be further examined. Finally, it seems worthwhile to replicate our study in a setting where the pay to performance relation has proved to be strong. 


\section{Bibliography}

Anderson, M. C., R. D. Banker, and S. Ravindran, 2000, Executive compensation in information technology industry, Management Sciences 46(4), 1411-1438.

Angbazo L. and R. Narayanan, 1997, Top management compensation and the structure of the board of directors in commercial banks, European Finance Review 1(2), 239-259.

Attaway, M., 2000, A study of the relationship between company performance and CEO compensation, American Business Review 18 (January), 77-85.

Ball, R. and L. Shivakumar, 2005, Earnings quality in U.K. private firms: comparative loss recognition timeliness, Journal of Accounting \& Economics, 39, 83-128.

Banghøj J. and T. S. Plenborg, 2008, The effect of stock pay and stock holdings on the pay to performance sensitivity, Working paper (Copenhagen Business School).

Bernstein L. A., and J. J. Wild, 1998 Analysis of financial statements, $5^{\text {th }}$ edition, (McGraw-Hill).

Boyd B. K., 1994, Board control and CEO compensation, Strategic Management Journal 15, 335344.

Boschen, J. F., A. Duru, L. A. Gordon, and K. J. Smith 2003, Accounting and stock price performance in dynamic CEO compensation arrangements, The Accounting Review 1, 143-168.

Brunello G., C. Graziano, and B. Parigi 2001, Executive compensation and firm performance in Italy, International Journal of Industrial Organization 19, 133-161. 
Buck T., A., C. Bruce, B. G. M. Main and H. Udueni, 2003, Long term incentive plans, executive pay and UK company performance, Journal of Management Studies 40, 1709-1727.

Cheng S. and M. Firth 2005, Ownership, corporate governance and top management pay in Hong Kong, Corporate Governance 13, 2, 291-302.

Chung K. H. and S. W. Pruitt 1996, Executive ownership, corporate value and executive compensation: A unifying framework, Journal of Banking and Finance 20, 1135-1159.

Cole, R.A. and H. Mehran 2008, What can we learn from privately held firms about executive compensation? Working Paper, (Federal reserve bank of New York staff report).

Conyon M. J., 1997, Corporate governance and executive compensation, International Journal of Industrial Organization" 15, 493-509.

Conyon, M. J. and K. J. Murphy 2000, The prince and the pauper? CEO pay in the United States and United Kingdom, The Economic Journal 110 (November), 640-671.

Core, J.E., R. W. Holthausen and D. F. Larcker, 1999, Corporate governance, chief executive officer compensation, and firm performance, Journal of Financial Economics 51, 371-406.

Duffheus P. and R. Kabir 2007, Is the pay-performance relationship always positive - evidence from the Netherlands, Journal of Multinational Financial Management 18, 45-60.

Eriksson, T and M Lausten, 2000, Managerial pay and firm performance - Danish evidence, Scandinavian Journal of Management 16, 269-286. 
Fama E. F. and M. C. Jensen 1983, Separation of ownership and control, Journal of law and Economics 26, 301-325.

Feltham G. A. and J. Xie 1994, Performance measure congruity and diversity in multi-task principal/agent relations, The Accounting Review 69, 429-453.

Fernandes N., 2008, EC: Board compensation and firm performance: The role of "independent" board members, Journal of Multinational Financial Management 18(1), 30-44.

Finkelstein S. and R. A. D'Aveni, 1994, CEO duality as double-edge sword: How boards of directors balance entrenchment avoidance and unity of command, Academy Journal of Management 37(5), 1079-1108.

Finkelstein S. and D. C. Hambrick, 1989, Chief executive compensation: A study of the intersection of markets and political processes, Strategic Management Journal, 10, 121-134.

Firth M., J. C. Lohne, R. Ropstad and J. Sjo, 1996, The remuneration of CEOs and corporate financial performance in Norway, Managerial and Decision Economics 17, 291-301.

Gabrielsen G., J. D. Gramlich, and T. S. Plenborg, 2002, Managerial ownership, information content of earnings, and discretionary accruals in a non-US setting, Journal of Business, Finance and Accounting 29, 967-988.

Gibbs M., K. A. Merchant, W. A. V. D. Stede, and M. E. Vargus, 2007, Performance measure properties and incentive system design, Working paper (University of Southern California). 
Green, D. and C. Riddell, 2001, Literacy, numeracy and labour market outcomes in Canada, Statistics Canada Catalogue, number 89-552-MIE2001008.

Haid, A. and B. B. Yurtoglu, 2006, Ownership structure and executive compensation in Germany, Working paper (Universität Erlangen-Nürnberg).

Hall, B and J B Liebman, 1998, Are CEOs really paid like bureaucrats?, The Quarterly Journal of Economics CXIII (3), 653-691.

Healy P. M., 1985, The effect of bonus schemes on accounting decisions, Journal of Accounting and Economics, 7, 85-107.

Hill C. W. L. and P. Phan 1991, CEO tenure as a determinant of CEO pay The Academy of Management Journal 34, 707-717.

Holmstrom B. and P. Milgrom, 1987, Aggregation and linearity in the provision of intertemporal incentives, Econometrica 55, 303-328.

Holthausen R. W. and D. F. Larcker, 1993, Boards of directors, ownership structure and CEO compensation, Working paper (Wharton school, University of Pennsylvania).

Iyengar R. J., H. J. Williams, and E. M. Zampelli, 2005, Sensitivity of executive pay to accounting performance measures in all-equity firms, Accounting and Finance, 45 577-595.

Jensen M., 1993, The modern industrial revolution. Exit, and the failure of internal control systems, Journal of Finance 48, 831-880. 
Jensen M. C. and W. H. Meckling, 1976, Theory of the firm: managerial behaviour, agency costs and ownership structure, Journal of Financial Economics 3, 305-360.

Jensen, M C and K J Murphy, 1990, Performance pay and top-management incentives, Journal of Political Economy 98 (2), 225-264.

Kaplan S. N., 1994, Top executive rewards and firm performance: a comparison of Japan and the United States, The Journal of Political Economy, 102, 510-546.

Kato T. and K. Kubo, 2003, CEO compensation and firm performance in Japan: Evidence from new panel data on individual CEO pay, Working paper (Columbia Business School).

Kato T., W. Kim and J. H. Lee, 2003, Executive compensation and firm performance in Korea, Working paper (Colgate University, Hamilton, NY)

Ke B., Petroni K., Safieddine A., 1999, Ownership concentration and sensitivity of executive pay to accounting performance measures: Evidence from publicly and privately-held insurance companies, Journal of Accounting and Economics 28, 185-209.

Lambert R. and D. Larcker, 1987, An analysis of the use of accounting and market measures of performance in executive compensation contracts, Journal of Accounting Research 25 (Supplement), 85-125.

Lambert R., D. Larcker and R. Verrecchia, 1993, The structure of organizational incentives, Administrative Science Quarterly 38, 438-461. 
Lippert R. L. and W. T. More, 1994, Compensation contracts of chief executive officers: Determinants of pay-performance sensitivity, Journal of Financial Research 3, 321-332.

Lippert R. L. and G. Porter, 1997, Understanding CEO pay:a test of two pay to performance sensitivity measures with alternative measures of alignment and influence, Journal of Business Research 40, 127-138.

Main B. G. M., A. Bruce and T. Buck, 1996, Total board remuneration and company performance, The Economic Journal, 106, 1627-1644.

McKnight P. J. and C. Tomkins, 1999, Top executive pay in the United Kingdom: a corporate governance dilemma, International Journal of the Economics of Business, 6(2), 223-243.

Murphy K. J., 1985, Corporate performance and managerial remuneration: an empirical analysis, Journal of Accounting and Economics VII, 11-42.

Murphy K. J., 1999, Executive compensation, in: Orley Ashenfelter and David Card. eds., Handbook of Labor Economics Vol 3 (North Holland) 1-90.

Murphy K. J., 2000, Performance standards in incentive contracts, Journal of Accounting and Economics 30(3), 245-278.

Oetomo and Swan, 2003, Can managerial superiority explain high executive pay in large firms? Evidence supportive of Rosen's 'cloning' hypothesis, Working Paper (University of New South Wales). 
O'Reilly C. A. III, B. G. Main and G. S. Crystal, 1988, CEO compensation as tournament and social comparison: a tale of two theories, Administrative Science Quarterly 33, 257-274.

Pedersen. T. and S. Thomsen, 1996, European patterns of corporate ownership: A twelve country study, Journal of International Business, Vol. 28, 759-778.

Penman S. H., 2007, Financial statement analysis and security valuation, $3^{\text {rd }}$ edition, (McGrawHill).

Petersen C. V.and T. S. Plenborg, 2007, How do firm implement impairment tests of goodwill?, Working paper, (Copenhagen Business School).

Pfeffer J., 1981, Power in Organizations (Pitman, Boston, MA).

Ramaswamy K., R. Veliyathm and L. Gomes, 2000, A study of the determinants of CEO compensation in India, Management International Review 40, 167-191.

Randhøy T. and J. Nielsen, 2002, Company performance, corporate governance and CEO compensation in Norway and Sweden, Journal of Management and Governance 6, 57-81.

Stock, J. H., J. H. Wright, and M. Yogo, 2002, A survey of weak instruments and weak identification in generalised method of moments, Journal of Business \& Economics Statistics, 20, 518-529.

Tosi H. L., S. Werner, J. P. Katz and L. R. Gomez-Mejia, 2000, How much does performance matter? A meta-analysis of CEO pay studies, Journal of Management, 26, 301-339. 
Watts, R. L. and R. W. Leftwich, 1977, The time series of annual accounting earnings, Journal of Accounting Research 15, 253-271.

Yermack D., 1996, higher market valuation for firms with a small board of directors, Journal of Financial Economics 40, 185-211.

Zhou X., 1999, Executive compensation and managerial incentives: A comparison between Canada and the United States, Journal of Corporate Finance, 5, 277-301.

Zhou X., 2000, CEO pay, firm size, and corporate performance: evidence from Canada, Canadian Journal of Economics 33, 213-250. 
Table 1

Descriptive statistics

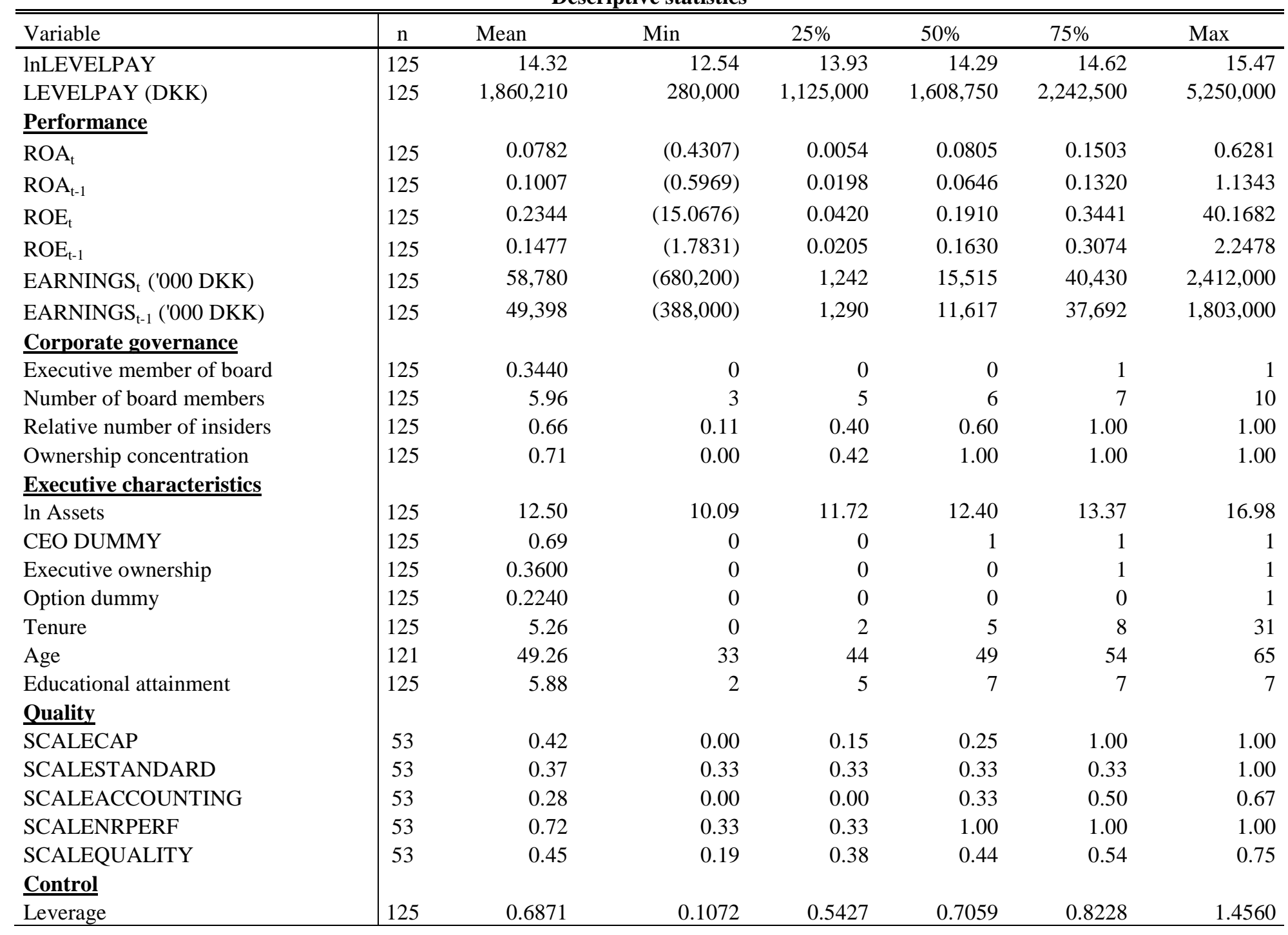




\section{DKK is Danish Kroner}

$\ln ($ LEVELPAY) is defined as the natural logarithm of the sum of total salary and bonus for the fiscal year

$\mathrm{ROA}_{\mathrm{t}}(\mathrm{t}-1)$ is the return on assets (lag return on assets) defined as EBIT divided by beginning of the fiscal year total assets.

$\operatorname{ROE}_{\mathrm{t}}(\mathrm{t}-1)$ is the return on equity (lag return on equity) defined as net earnings divided by beginning of the fiscal year book value of equity

EARNINGS $_{\mathrm{t}(\mathrm{t}-1)}$ is the net results (lag net result) in thousands for the fiscal year

Executive member of board is an indicator variable that equals 1 if the executive holds a position on the supervisory board and zero otherwise

Number of board members is defined as the number of members of the supervisory board.

Relative number of insiders is defined as the percentage of board members who are insiders.

Ownership concentration is the percentage of shares owned by the largest shareholder

Ln Assets is the natural logarithm of beginning of fiscal year total assets.

CEO DUMMY is an indicator variable that equals one if executive hold the position as CEO and zero otherwise

Executive ownership is an indicator variable that equals one if the executive ownes shares in the company and zero otherwise

Option is an indicator variable that equals one if the executive holds options in the company and zero otherwise

Tenure is defined as the number of years the executive has hold the current position in the firm.

Age is the age of the executive

Educational attainment is an indicator variable running from 1-7 where 1 indicates primary and lower-secondary school and 7 indicates a graduate degree.

SCALECAP is a variable that (from 0-1) indicates the span over which the incentive zone is in the compensation contract.

SCALESTANDARD indicates the use of internal, combination or external standards, where external standards receive the highest score

SCALEACCOUNTING indicates whether the performance measures in compensation contracts is adjusted for changes in accounting policies or transitory items. 1 indicates the highest level.

SCALENRPERF indicates how many performance measures are included in the compensation contract. 3 or more is coded identically.

SCALEQUALITY is a qualityindex that ranks each bonus plan based on four quality indicators. Each bonus plan is ranked from 0 to 1 based

on the average score of the four quality indicators

Leverage is defined as total debt divided by total assets. 
Table 2

Pearson Correlations between compensation and determinants

\begin{tabular}{|c|c|c|c|c|c|c|c|c|c|c|c|c|c|c|}
\hline & $\mathrm{ROA}_{\mathrm{t}}$ & $\mathrm{ROA}_{\mathrm{t}-1}$ & $\begin{array}{l}\text { Executive } \\
\text { member of } \\
\text { board }\end{array}$ & $\begin{array}{c}\text { Number of } \\
\text { board } \\
\text { members }\end{array}$ & $\begin{array}{c}\text { Relative } \\
\text { number of } \\
\text { insiders }\end{array}$ & $\begin{array}{l}\text { Ownership } \\
\text { concentration }\end{array}$ & ln Assets & $\begin{array}{c}\text { CEO } \\
\text { DUMMY }\end{array}$ & $\begin{array}{c}\text { Executive } \\
\text { ownership } \\
\text { dummy }\end{array}$ & Tenure & Age & $\begin{array}{c}\text { Educational } \\
\text { attainment }\end{array}$ & Leverage & $\begin{array}{l}\text { SCALE- } \\
\text { QUALITY }\end{array}$ \\
\hline \multirow[t]{2}{*}{ InLEVELPAY } & 0.0704 & 0.1141 & -0.0747 & 0.3254 & 0.0516 & 0.1013 & 0.5339 & 0.1557 & -0.0609 & 0.0469 & 0.0109 & 0.1869 & -0.1708 & -0.6361 \\
\hline & 0.4355 & 0.2053 & 0.4077 & 0.0002 & 0.5680 & 0.2611 & $<.0001$ & 0.0829 & 0.5002 & 0.6033 & 0.9057 & 0.0369 & 0.0569 & 0.6509 \\
\hline \multirow[t]{2}{*}{$\mathrm{ROA}_{\mathrm{t}}$} & & 0.6578 & 0.0375 & -0.0389 & 0.0104 & 0.0814 & -0.0714 & -0.0463 & 0.0131 & 0.1099 & -0.2965 & -0.0031 & -0.3035 & 0.1490 \\
\hline & & $<.0001$ & 0.6778 & 0.1613 & 0.9088 & 0.3669 & 0.4288 & 0.6080 & 0.8848 & 0.2225 & 0.0010 & 0.9723 & 0.0006 & 0.2868 \\
\hline \multirow[t]{2}{*}{$\mathrm{ROA}_{\mathrm{t}-1}$} & & & 0.1067 & -0.0912 & 0.0419 & 0.1355 & -0.0552 & 0.0252 & 0.1091 & 0.0746 & -0.0322 & 0.0250 & -0.4120 & 0.0844 \\
\hline & & & 0.2364 & 0.3116 & 0.6431 & 0.1319 & 0.5413 & 0.7804 & 0.2258 & 0.4084 & 0.7256 & 0.7816 & $<.0001$ & 0.5481 \\
\hline \multirow{3}{*}{$\begin{array}{l}\text { Corporate governance } \\
\text { Executive member of board }\end{array}$} & & & & & & & & & & & & & & \\
\hline & & & & -0.2823 & 0.2587 & 0.0468 & -0.3473 & 0.3059 & 0.2989 & 0.0783 & -0.7995 & -0.1631 & 0.0471 & -0.1211 \\
\hline & & & & 0.0014 & 0.0036 & 0.6040 & $<.0001$ & 0.0005 & 0.0007 & 0.3852 & 0.3834 & 0.0691 & 0.6018 & 0.3876 \\
\hline \multirow[t]{2}{*}{ Number of board members } & & & & & -0.2653 & -0.1700 & 0.4269 & -0.0976 & -0.1320 & -0.0471 & 0.0998 & 0.2174 & -0.0425 & -0.0698 \\
\hline & & & & & 0.0028 & 0.0581 & $<.0001$ & 0.2789 & 0.1422 & 0.6016 & 0.2760 & 0.0149 & 0.6381 & 0.6193 \\
\hline \multirow[t]{2}{*}{ Relative number of insiders } & & & & & & 0.0653 & -0.0402 & 0.1901 & -0.1597 & 0.0053 & -0.1709 & 0.0310 & 0.1285 & 0.2809 \\
\hline & & & & & & 0.4694 & 0.6565 & 0.0337 & 0.0753 & 0.9532 & 0.0609 & 0.7313 & 0.1532 & 0.0416 \\
\hline \multirow[t]{2}{*}{ Ownership concentration } & & & & & & & 0.0098 & -0.1229 & -0.1983 & -0.1846 & -0.0505 & -0.0744 & -0.0354 & 0.1612 \\
\hline & & & & & & & 0.9136 & 0.1723 & 0.0267 & 0.0393 & 0.5825 & 0.4098 & 0.6950 & 0.2489 \\
\hline \multicolumn{15}{|l|}{ Executive characteristics } \\
\hline \multirow[t]{2}{*}{ ln (Assets) } & & & & & & & & -0.2125 & -0.1523 & 0.1306 & 0.1010 & 0.1464 & -0.1307 & 0.1529 \\
\hline & & & & & & & & 0.0174 & 0.0900 & 0.1466 & 0.2701 & 0.1032 & 0.1464 & 0.2745 \\
\hline \multirow[t]{2}{*}{ CEO DUMMY } & & & & & & & & & 0.0734 & 0.0288 & 0.0756 & -0.1291 & -0.0272 & -0.1199 \\
\hline & & & & & & & & & 0.4160 & 0.7496 & 0.4099 & 0.1514 & 0.7630 & 0.3925 \\
\hline \multirow[t]{2}{*}{ Executive ownership dummy } & & & & & & & & & & 0.0237 & 0.1082 & -0.0070 & -0.6426 & -0.1569 \\
\hline & & & & & & & & & & 0.7934 & 0.2373 & 0.9383 & 0.4765 & 0.2619 \\
\hline \multirow[t]{2}{*}{ Tenure } & & & & & & & & & & & -0.4713 & 0.0209 & -0.1332 & 0.0029 \\
\hline & & & & & & & & & & & 0.6077 & 0.8174 & 0.1388 & 0.9837 \\
\hline \multirow[t]{2}{*}{ Age } & & & & & & & & & & & & 0.0189 & 0.0882 & 0.1099 \\
\hline & & & & & & & & & & & & 0.8370 & 0.3363 & 0.4381 \\
\hline \multirow[t]{2}{*}{ Educational attainment } & & & & & & & & & & & & & 0.0025 & 0.1121 \\
\hline & & & & & & & & & & & & & 0.9783 & 0.4241 \\
\hline \multirow{3}{*}{$\frac{\text { Control }}{\text { Leverage }}$} & & & & & & & & & & & & & & \\
\hline & & & & & & & & & & & & & & -0.1070 \\
\hline & & & & & & & & & & & & & & 0.4456 \\
\hline
\end{tabular}

$\mathrm{n}=125$ except for the variables Age and SCALEQUALITY where $\mathrm{n}$ is 121 and 53, respectively

The first number is the Pearson correlation coefficient, second number is the P-value under the null hypothesis of zero correlation 
TABLE 3

Two-stage least squares estimation of log level of pay on performance, size, Corporate Governance variables, executive characteristics, and quality of contract

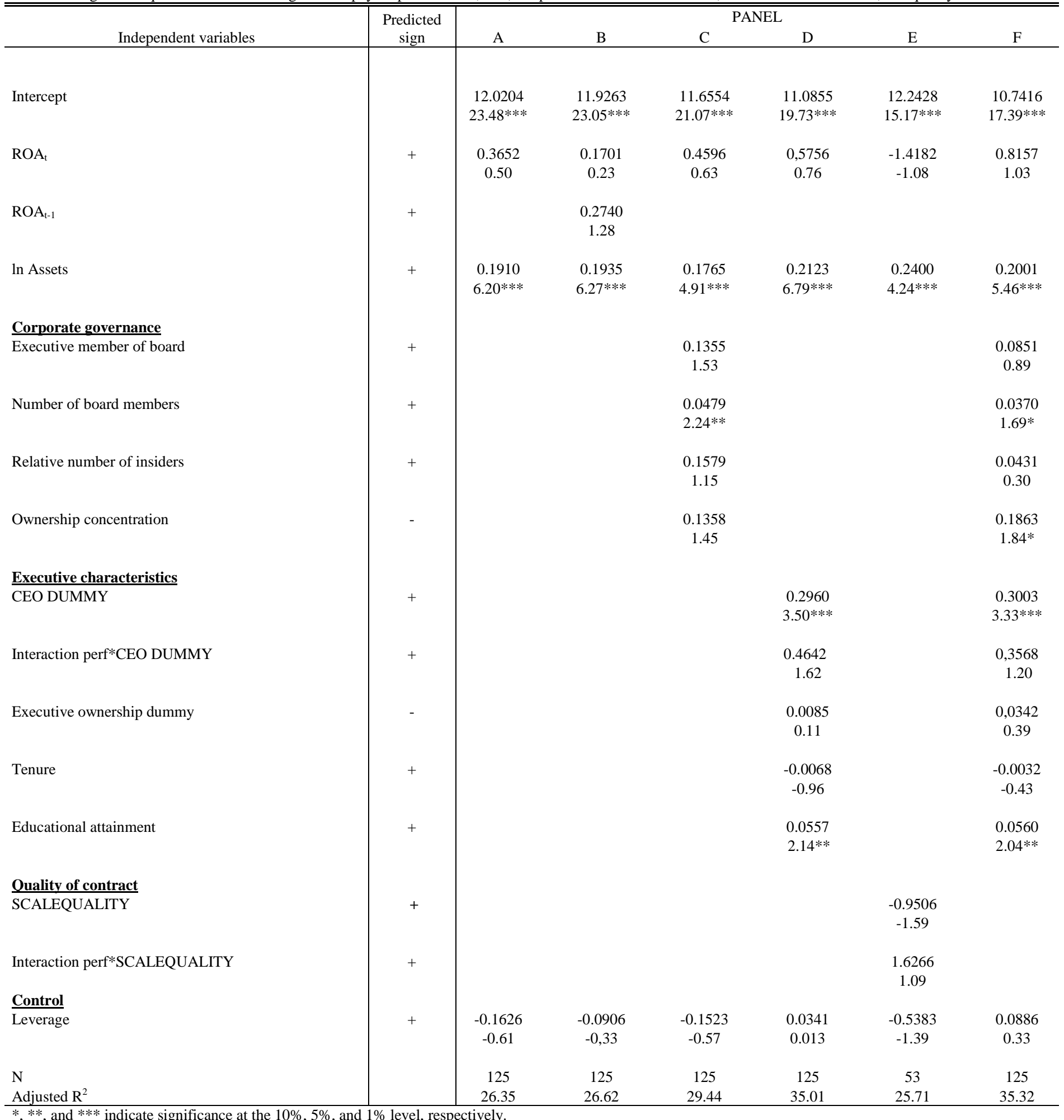

$*, * *$, and $* * *$ indicate significance at the $10 \%, 5 \%$, and $1 \%$ level, respectively.

See table 1 for description of the variables. 
TABLE 4

Two-stage least squares estimation of log level of pay on performance, size, Corporate Governance variables, executive characteristics, and quality of contract

\begin{tabular}{|c|c|c|c|c|c|c|}
\hline \multirow[b]{2}{*}{ Independent variables } & \multirow[b]{2}{*}{ Predicted sign } & \multicolumn{5}{|c|}{ PANEL } \\
\hline & & A & B & $\mathrm{C}$ & $\mathrm{D}$ & E \\
\hline & & $\begin{array}{l}\text { SCALE } \\
\text { QUALITY }\end{array}$ & $\begin{array}{l}\text { SCALENR } \\
\text { PERF }\end{array}$ & $\begin{array}{c}\text { SCALE } \\
\text { ACCOUN- } \\
\text { TING }\end{array}$ & $\begin{array}{c}\text { SCALE } \\
\text { STANDARD }\end{array}$ & $\begin{array}{l}\text { SCALE } \\
\text { CAP }\end{array}$ \\
\hline Intercept & & $\begin{array}{c}11.6078 \\
13.22 * * *\end{array}$ & $\begin{array}{c}11.0759 \\
12.40^{* * *}\end{array}$ & $\begin{array}{c}11.3704 \\
12.67 * * *\end{array}$ & $\begin{array}{c}11.7089 \\
12.76^{* * *}\end{array}$ & $\begin{array}{c}12.1210 \\
11.55^{* * *}\end{array}$ \\
\hline $\mathrm{ROA}_{\mathrm{t}}$ & + & $\begin{array}{l}-0.6021 \\
-0.54\end{array}$ & $\begin{array}{l}-0.1105 \\
-0.10\end{array}$ & $\begin{array}{l}-0.703 \\
-0.61\end{array}$ & $\begin{array}{l}-0.5894 \\
-0.52\end{array}$ & $\begin{array}{l}-1.5843 \\
-1.23\end{array}$ \\
\hline ln Assets & + & $\begin{array}{c}0.1939 \\
3.16^{* * *}\end{array}$ & $\begin{array}{l}0.2317 \\
3.55^{* * *}\end{array}$ & $\begin{array}{c}0.1915 \\
2.99 * * *\end{array}$ & $\begin{array}{c}0.1591 \\
2.38 * * *\end{array}$ & $\begin{array}{c}0.1356 \\
1.83^{* * *}\end{array}$ \\
\hline$\frac{\text { Corporate governance }}{\text { Executive member of board }}$ & + & $\begin{array}{c}-0.019 \\
0.01\end{array}$ & $\begin{array}{c}0.0442 \\
0.33\end{array}$ & $\begin{array}{c}0.0221 \\
0.15\end{array}$ & $\begin{array}{c}-0.0048 \\
-0.03\end{array}$ & $\begin{array}{c}-0.082 \\
-0.48\end{array}$ \\
\hline Number of board members & + & $\begin{array}{l}0.0717 \\
2.06^{* *}\end{array}$ & $\begin{array}{c}0.0481 \\
1.35\end{array}$ & $\begin{array}{l}0.0749 \\
2.05^{* *}\end{array}$ & $\begin{array}{l}0.0809 \\
2.10^{* *}\end{array}$ & $\begin{array}{l}0.0875 \\
2.23^{* *}\end{array}$ \\
\hline Relative number of insiders & + & $\begin{array}{c}0.1572 \\
0.74\end{array}$ & $\begin{array}{c}0.3077 \\
1.40\end{array}$ & $\begin{array}{c}0.0728 \\
0.33\end{array}$ & $\begin{array}{c}0.1452 \\
0.63\end{array}$ & $\begin{array}{c}0.0442 \\
0.19\end{array}$ \\
\hline Ownership concentration & - & $\begin{array}{c}0.2336 \\
1.49\end{array}$ & $\begin{array}{c}0.1917 \\
1.30\end{array}$ & $\begin{array}{c}0.2031 \\
1.27\end{array}$ & $\begin{array}{c}0.1588 \\
1.01\end{array}$ & $\begin{array}{l}0.2510 \\
1.48\end{array}$ \\
\hline$\frac{\text { Executive characteristics }}{\text { CEO DUMMY }}$ & + & $\begin{array}{l}0.3305 \\
2.16^{* *}\end{array}$ & $\begin{array}{l}0.2845 \\
2.03^{* *}\end{array}$ & $\begin{array}{l}0.3078 \\
2.12^{* *}\end{array}$ & $\begin{array}{l}0.2287 \\
1.42\end{array}$ & $\begin{array}{l}0.4322 \\
2.63^{* *}\end{array}$ \\
\hline Interaction perf*CEO DUMMY & + & $\begin{array}{l}0.8236 \\
0.76\end{array}$ & $\begin{array}{c}0.6964 \\
0.75\end{array}$ & $\begin{array}{c}1.0022 \\
1.57\end{array}$ & $\begin{array}{l}2.3374 \\
1.78^{*}\end{array}$ & $\begin{array}{c}0.4005 \\
0.49\end{array}$ \\
\hline Executive ownership dummy & - & $\begin{array}{c}0.0861 \\
0.65\end{array}$ & $\begin{array}{c}0.1014 \\
0.79\end{array}$ & $\begin{array}{c}0.079 \\
0.57\end{array}$ & $\begin{array}{c}0.0618 \\
0.45\end{array}$ & $\begin{array}{c}0.0779 \\
0.53\end{array}$ \\
\hline Tenure & + & $\begin{array}{l}-0.0203 \\
-1.87^{*}\end{array}$ & $\begin{array}{l}-0.0222 \\
-2.13^{* *}\end{array}$ & $\begin{array}{l}-0.0214 \\
-1.82 *\end{array}$ & $\begin{array}{l}-0.0235 \\
-2.06 * *\end{array}$ & $\begin{array}{c}-0.0200 \\
-1.67\end{array}$ \\
\hline Educational attainment & + & $\begin{array}{l}0.0529 \\
1.36\end{array}$ & $\begin{array}{c}0.0559 \\
1.49\end{array}$ & $\begin{array}{c}0.0385 \\
0.97\end{array}$ & $\begin{array}{c}0.0334 \\
0.83\end{array}$ & $\begin{array}{l}0.0508 \\
1.19\end{array}$ \\
\hline$\frac{\text { Quality of contract }}{\text { QUALITY }}$ & + & $\begin{array}{l}-1.0359 \\
-1.90^{*}\end{array}$ & $\begin{array}{l}-0.5206 \\
-2.13^{* *}\end{array}$ & $\begin{array}{l}-0.1481 \\
-0.55\end{array}$ & $\begin{array}{c}0.3781 \\
0.56\end{array}$ & $\begin{array}{l}-0.4314 \\
-1.45\end{array}$ \\
\hline Interaction perf*QUALITY & + & $\begin{array}{c}0.8527 \\
0.37\end{array}$ & $\begin{array}{c}0.2181 \\
0.22\end{array}$ & $\begin{array}{c}0.6327 \\
0.34\end{array}$ & $\begin{array}{c}-2.7770 \\
-1.08\end{array}$ & $\begin{array}{c}2.691 \\
1.49\end{array}$ \\
\hline$\frac{\text { Control }}{\text { Leverage }}$ & + & $\begin{array}{l}-0.4463 \\
-1.31\end{array}$ & $\begin{array}{l}-0.4385 \\
-1.33\end{array}$ & $\begin{array}{l}-0.4139 \\
-1.14\end{array}$ & $\begin{array}{l}-0.4582 \\
-1.26\end{array}$ & $\begin{array}{c}-0.5411 \\
-1.41\end{array}$ \\
\hline $\mathrm{N}$ & & 53 & 53 & 53 & 53 & 53 \\
\hline Adjusted $\mathrm{R}^{2}$ & 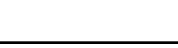 & 48.87 & 51.81 & 43.82 & 44.57 & 41.54 \\
\hline
\end{tabular}

TABLE 5

Panel A 


\begin{tabular}{l|c|c}
\hline \hline \multicolumn{1}{c|}{ Independent variables } & Predicted sign & \\
\hline & & \\
Intercept & & 7.8242 \\
& & $9.79 * * *$ \\
DeltaROA & + & 0.3561 \\
& & 0.60 \\
$\ln$ (Assets) & + & 0.2719 \\
& & $4.26 * * *$ \\
$\mathrm{~N}$ & & 87 \\
Adjusted $\mathrm{R}^{2}$ & & 15.99 \\
\hline
\end{tabular}

Panel B

Two-stage least squares estimation of log level of pay on lag log level of pay $\mathrm{t}_{\mathrm{t}-1}$, change in performance, and size

\begin{tabular}{|c|c|c|}
\hline Independent variables & Predicted sign & \\
\hline Intercept & & $\begin{array}{c}0.3479 \\
1.76^{*}\end{array}$ \\
\hline $\ln (\text { LEVELPAY })_{\mathrm{t}-1}$ & + & $\begin{array}{c}0.9682 \\
61.78 * * *\end{array}$ \\
\hline DeltaROA & + & $\begin{array}{c}-0.0235 \\
-0.57\end{array}$ \\
\hline $\ln$ (Assets) & + & $\begin{array}{l}0.0124 \\
2.23 * *\end{array}$ \\
\hline $\mathrm{N}$ & & 114 \\
\hline Adjusted $\mathrm{R}^{2}$ & & 97.94 \\
\hline
\end{tabular}

*, **, and *** indicate significance at the $10 \%, 5 \%$, and $1 \%$ level, respectively.

See table 1 for description of the variables. 